\title{
Studies on Melanin.
}

VI. The Genesis of the Nevus Cell.

\author{
By \\ Minor Ito. \\ （伊 藤 筫）
}

(From the Department of Dermatology, Faculty of Medicine, Tohoku University, Sendai. Director: Prof. M. I to.)

(Received for publication, April 21, 1949)

Research on the genesis of the nevus cell in pigmented nevi is being carried on by many investigators. First came the Fibroblast theory (Simon, Rokitanski and Virchow), then the Bloodvessel-wallcell theory (Demieville), next the Lymphatic-vessel-endothelialcell theory (Recklinghausen) and the Chromatophore theory (Ribbert). These accentuate the mesenchymal origin. But when the Abtropfung theory was proposed by Unna, it was accepted by many investigators, especially on account of the dopa reaction of Bloch ${ }^{11}$ that leads to the theory of the skin nerv origin of Masson $^{2)}$ which is being much discussed.

I have also made a study of the above subject. First of all, I concentrated on the examination of the relationship between the skin nerve and nevus cells by the advanced method of Bielschowsky's silver impregnation of neurofibril (Prof. Seto, ${ }^{3}$ Tohoku University) and then discussed the problem of fiber formation of nevus cell by the Gitterfaser staining of Bielschowsky-Maresch.

Materials were taken from 13 patients and were fixed at least 10 months in neutral formalin (Seto's method). Sections about $30 \mu$ in thickness were made, stained and biopsied. At the same time, I studied the histology of neurofibroma, neurinoma, malignant melanoma, blue nevus and mongolian spot by the same method.

1. Microscopic studies of the Bielschowsky-Seto's neurofibril staining preparations. At nevus lesions the neurofibril bundles are prominent at the deeper layer of the derm under low power microscope, reminding one of the Polineurie of the French school. At places where nerve bundles penetrate or run close to nevus cell nest, their Schwann's cells are much increased in number. The nuclei of these Schwann's cells are so hypertrophied in a circuloid form that the nerve bundles seem to swell as a whole mixed with nevus cells, and consequently it is difficult to differentiate the nevus cell nucleus from that of the Schwann's cell either morphologically 
or dispositionally. The fine ramificated neurofibrils coil round the nerve bundle like a gabion, and their Schwann's nuclei give the impression of transition to nevus cells (see Fig. 1).

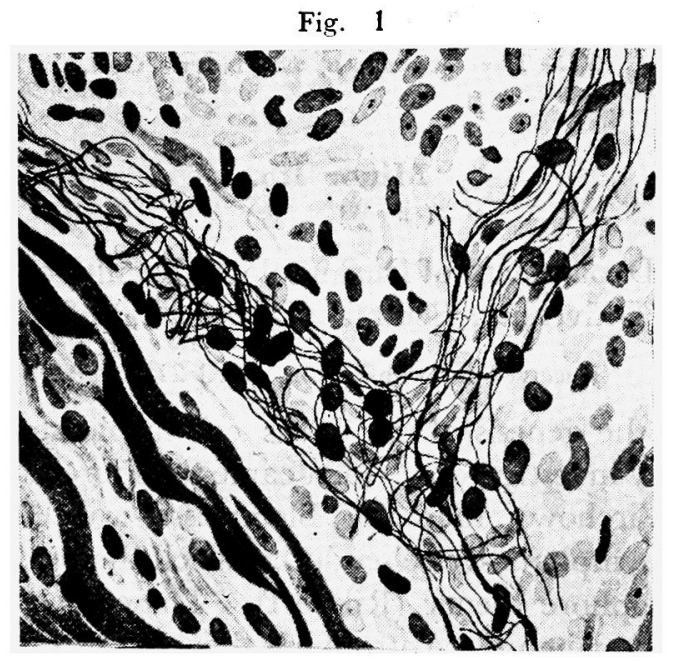

We can see more or less in all specimens neurofibrils running into the nevus cell nest of reticulated midlayer, and especially in several preparations the cross and oblique sections of nerve bundles are visible. The biopsy shows the particular figure of several looped and ramificated nerve bundles between nevus cells. The nuclei of Schwann's cells are typical long-oval and bend together with neurofibrils but some nuclei are so swollen that we can not distinguish them from nevus cells (Fig. 2).

Fig. 2

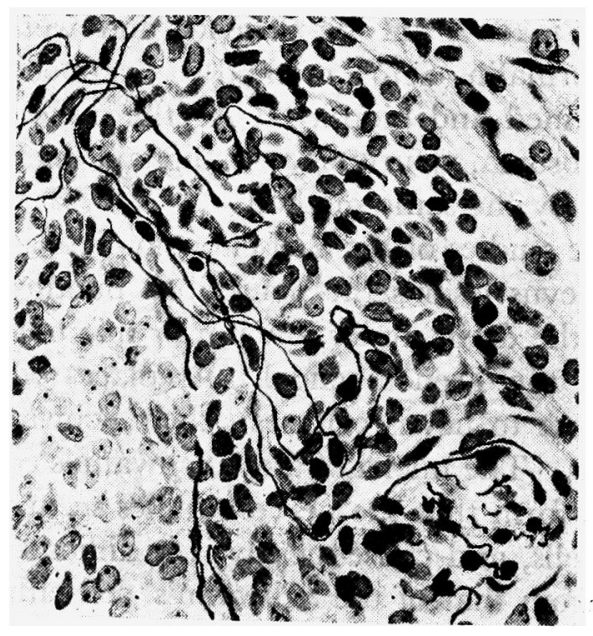


Several magnitudes of nevus cell nest and single nevus cell are situated sporadically and they come into contact with the course of one or two neurofibrils and fine vegetable nerve (Fig. 3).

Fig. 3

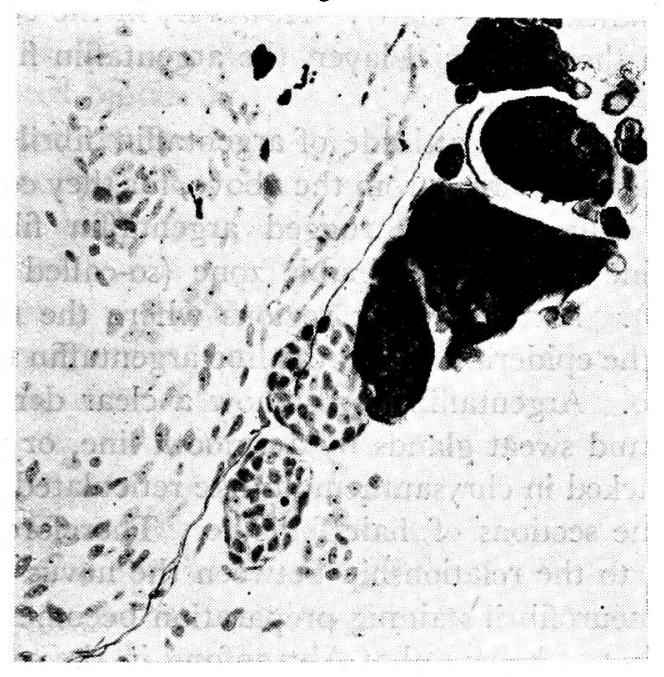

In several specimens of young children suggestive of early stage, nevus cells exist diffusely in the spongy tissue without the nest formation. The shapes of the cells are round, oval, comma-shaped or rarely stellate and some of them are connected with each other by their dendrites. We can see between them fine bundle of neurofibrils and nevus cell groups situated in the same course with neurofibrils. Sometimes the Schwann's cell and the nevus cell are twisted with each other and this fact shows the morphological transition between these two cells. In my observation of several specimens, I recognized the figure of something resembling endoneural apparatus, on which Masson based his nerve cell theory, i.e., morphlogy of Fibres naeviques, Faisceau neuroid, Lames foliacées, Corpuscules naeviques and Cellules claires in basal membrane.

The blood vessels are found near or in nevus cell nest but $I$ have not been able to find any figure which shows the relationship between these vessel-wallcells and nevus cells or their transition in any part. The Abtropfung figure is refuted by the following observations of Gitterfaser staining slides.

2. Microscopic studies of the Bielschowsky-Maresch's Gitterfaser staining preparations. Results of observations are similar in all preparations, i.e., the nevus cell nests are completely packed with argentaffin fibrils which penetrate into the nests and show the fine reticulated ap- 
pearance, and each nevus cell looks as if it is inlayed in each reticulum. Especially at some places where nevus cells are scarcely located, closely united figures of argentaffin fibrils and nevus cell protoplasma, and also the nevus cells, abundant with melanin, sticking to argentaffin fibrils botrioidally, are indicated distinctly. However, in the central part of big nevus cell nests in the superficial layer, the argentaffin fibril is not clearly stained out.

On the other hand, the attitude of argentaffin fibrils toward the epidermal layer is utterly different from the above, for they confront with each other decidedly. The minutely rugged argentaffin fibrils are located separately from fine clear non-stainable zone (so-called hyalinous membrane of Ranvier). Particularly at regions where the nevus cell nest is projected against the epidermal layer, the fine argentaffin fibrils draw a line between these two. Argentaffin fibrils show a clear demarcation against sebaceous glands and sweat glands by a smooth line, or pretty nevus cell nests which are packed in chrysanthemum-like reticulated picture observed around the oblique sections of hair follicule. Therefore, as the unclear point with regard to the relationship between the nevus cell and the epidermis in former neurofibril staining preparation becomes clear by Gitterfaser staining, I do not believe that Abtropfung in the sence of Unna can be upheld. Moreover, I have confirmed these observations by Mallory's staining.

\section{Comment.}

1. The relationship between the nevus cell and the skin nerve. In 1899, Soldan advocated that nevus cell belongs to a tumor of connective tissue cells originated from neurofibril sheath, but people took no notice of his opinion as just then the Abtropfung theory of Unna was becoming influential. However, in 1926 Masson $^{2)}$ established the neural origin theory of nevus cells that was founded on the observations by his own method called Trichrome staining. According to him, the nevus cell comes from Cellules claires that corresponds to the Merkel-Ranvier's tactile cell in the epidermis. He pointed out the Fibres naeviques, Faisceau neuroide, Lames foliacées, Corpuscules naeviques in the derm and considered the nevus cell as a special form of skin nerve which has lost its sheath and axiscylinder but has proliferated Schwann's cell. This excellent new theory called attention of the investigators. Chandler Foot ${ }^{4}$ first supported it. Miescher ${ }^{5)}$ and Albertini made a supplemental experiment of Masson's method and they both helped to uphold the new theory. Then Feyrter, $\left.{ }^{6}\right)$ suspecting its origin to be the endothelcell-like Häutchenzelle which is located between the external sheath of nerve, recognized this fact by a special myelinsheath staining. John") continued the study by the Biel- 
schowsky-Gros's method and noticed the swelling and karyocytosis of Schwann's sheath as well as the abnormal course and ramification of neurofibril in nevus cell nest. He considered these as a manifestation of periferal nervous reaction which concerns the whole nerve tissue and noticed the Stalagmocyten in the epidermis, a type of proliferation and agreed to the bipolar theory. Ota ${ }^{8)}$ obtained analogous results to that of Masson, and therefore, advocated bipolarity.

I made clearer preparation by Seto's excellent modification. On account of the nature of the nerve tissue, I am unable to regard the abnormal figure of neurofibrils in nevus cell nests to be a simple incidental or passive transformation, but $\mathrm{I}$ am inclined to believe it has some active or causative relationship to the nevus cell formation. Especially in the Figure 1, I can see the process of transition of Schwann's cell of neurofibril to nevus cell by the twisting of the nerve bundles in the deeper layer like a gabion. I believe the above observation is the best evidence which support the theory of Schwann's cell origin of Masson.

2. The relationship between nevus cell and argentaffin fibrils. Demieville, Dalla Favera, Bauer, Löwenbach, Abesser, Ribbert, Oppenheim and others proved that there are fibrous substances around the nevus cells which penetrate into the nest reticulately. With regard to the origin of these substances, Dalla Favera, Takeuchi and others assumed that the nevus cell infiltrates into collagenic fibers, while Unna, Abesser, Fick and others considered the substances as a new born fiber from existing connective tissue. However, a school which maintains the mesenchymal origin of nevus cells (Recklinghausen, Bauer, Scheuber, Ribbert, Krompecher, Borst and Hausemann, Fischer and others) regards the fibrous substances as a product of nevus cells. But Kromeyer, together with Judalewitsch, suggested that the epidermal cell first drip down and then change into the connective tissue. He advocated this phenomenon as Desmoplasie. Másson advanced the theory that the fiber originated from the substratum of Schwann's sheath. Then Lucioni, Cohn, Chandler Foot, Feyrter and others recognized that the nevus cell is packed with reticulated fiber by several silver impregnations and advanced their own theories.

If we are to consider the argentaffin figrils as the Gitterfaser in a narrow sence, my observation leads us to call our attention to the reticuloendothelial tissue and it becomes favorable to the mesenchymal theory and conflicts with my own observation in the foregoing paragraph. But we can not consider the argentaffin fibrils to be always mesenchymal, especially, since Sekine ${ }^{9)}$ explicated recently in his embryo-morphological study that there exists neurogenic variety of argentaffin fibrils as well as mesenchymal and epithelial ones. So he recognized that the Neurilemmafaser is no other than the Schwann's sheath and that this argentaffin fibril is separ- 
ated from the collagenic fiber of internal sheath and, therefore, held that it should undoubtedly belong to the neuro-ectodermal origin. On the other hand I identified the argentaffin fibril of the Schwann's cell on the Bielschowsky-Maresch's staining preparation of neurofibroma and neurinoma which I studied for the sake of consultation. It can be affirmed that the argentaffin fibril in my slides of nevus cell is the neurogenic fibril which originates from the Schwann's cell, and consequently, the theory of Soldan and Feyrter that maintains the origin to be the internal and external sheath of neurofibril can be refuted at the same time. But the parade-like arrangement such as seen in a neurinoma is scarcely found in nevus cells. This is easy to understand when we think of the difference between neurinoma which comes out in non-peripheral nerve bundle, and nevus cell which is a lesion at the periphery of skin nerves. The attitude of argentaffin fibrils on the epidermal layer is very clear as reported previously. Even at places where nevus cell nests come close to the epidermal layer, I have always maintained the presence of argentaffin fibrils. This fact corresponds to the presence of the so-called Randbindegewebe between nevus cell nest and epidermis which was noticed by Bauer ${ }^{10}$ ) and traced by Demieville, Ribbert, Wieting and Hamdi, Soldan, Berblinger and others. I note such fact as a counter-evidence of Unna's Abtropfung theory.

3. The relationship between nevus cell and melanin. In accordance with the Abtropfung theory of Unna, the Dopa-oxydase theory of Bloch seems to be convincing of the ectodermal origin of nevus cells. But there is much doubt with regard to the theory, as Kissmeyer, Kaiserling and others have already pointed out. Moreover, the instance of dopa-positiveness in blue nevus and mongolian spot observed by Sato and Bahrawy of Bloch's school is not necessarily favorable to epidermal theory and I believe I can show the mistake of epidermal nature in my comparative study of blue nevus and mongolian spot, which I believe to be of mesenchymal nature.

Inclusion of melanin is not necessary in nevus cells, although abundance of melanin is generally found in the superficial nevus cells and it can also be found in the deeper cell nest or in scattered nevus cells. This fact is unexplainable as a photodynamic reaction and we are to find the new signification of dopa-reaction on this point. And I observed by Bielschowsky-Seto's staining preparation the vegetable neurofibril and its endoreticulum, particularly at parts where melanin is found in nevus cell nest or in scattered nevus cells. I also noticed such contact of vegetable neurofibril in the comparative study of malignant melanoma, blue nevus and mongolian spot. Therefore it is evident that there exists some relationship between vegetable nerve fibrils and melanin production. Namely, if a cell, be it a nevus cell of neuroectodermal origin or mesenchymal chromatophore (as it is the case with a mongolian spot), has some contact with the 
termination of vegetable nerve fibrils, then the cell is possessed of melanogenic facility. Consequently, it may be assumed that melanin production is the result of the chemical transmission of vegetable nerve in the so-called Erfolgzelle, or shortly, a neurohormonal reaction (Vielter). Therefore it is proper to assume the participation of oxydase. The dopa-reaction, I conclude, is no other than a sign which reveals the secret of this process.

\section{SumMary.}

1. By means of the Bielschowsky-Seto's method of neurofibril staining, the author have concluded that the nevus cell is not the production of the "Abtropfung" of epidermis (Unna), but originates from the neuroectodermal cell which is homogenetic with the Schwann's cell of Masson.

2. I have recognized the argentaffinity of the Schwann's cell by Bielschowsky-Maresch's staining, and have supported the neurogenic nature of nevus cell. But I am obliged to regect the so-called Abtropfung theory on account of the indifferent attitude of argentaffin fibril against the epidermis.

3. The author believes the melanin production depends entirely upon the chemical reaction in the cell which is in contact with the termination of peripheral vegetable nerve, and that it does not matter whether the cell is ectodermal or mesodermal.

\section{References.}

1) Bloch, Jadassohns Handb. I, 1927.

2) Masson, Ann. d. anat. path., 1926, 3, 657.

3) Seto, Arb. Anat. Inst. Univ. Sendai, 1942, 25, 99.

4) Chandler Foot, Americ. J. Path., 1932, 8, 309.

5) Miescher, Jadassohns Handb. XII/3, 1933.

6) Feyrter, Virchows Arch., 1938, 301, 417.

7) John, Arch. f. Derm., 1939, 178. 607.

8) Ota, Jap. J. Derma. \& Urol., 1940, 47, 376.

9) Sekine, Gan, 1943, 37, 147.

10) Bauer, Virchows Arch., 1895, 142, 407. 